\title{
Simulation of the Behavior of a Cracked Head of Shoulder Prosthesis
}

\author{
Belkacem Meddour \\ Laboratoire d'Ingénierie et Sciences des Matériaux Avancés ISMA, \\ Department of Mechanical Engineering, Abbas Laghrour University, Khenchela, Algeria
}

(Received 10 June 2020; revised manuscript received 22 December 2020; published online 25 December 2020)

\begin{abstract}
The health safety of the human being is one of the most important goals of governments around the world. The cessation of the functioning of any organ of the human body would have a negative impact on psychological and physical health of the patient. The replacement of the damaged organ by an artificial organ is the used solution. The shoulder joint is an example; a total prosthesis can be implanted to recover the functioning of the upper limb. The right choice of materials for this prosthesis is one of the research directions today. The purpose of this work is to predict the propagation of the crack previously created in the head of the shoulder prosthesis. Shoulder prosthesis is composed of two components: a head made usually of inoxydable steel or metallic alloys and a cup which could be made of UHMWPE. The proposed material of the head was alumina. As bioceramics, alumina has known properties that make it a candidate material to replace used stainless steel or metallic alloys. But fragility is the most undesirable alumina property. So to investigate its tenacity prior defects were created and to extend the investigation two cases of remarkable location of the prior crack were considered. The selected mean of simulation is the finite element calculation code Abaqus. The needed data: geometries of the two compounds of the shoulder prosthesis, loads and mechanical properties of the considered material were implemented. The obtained results concerned normal stresses at the tip and the line of propagation of prior cracks. The calculation of intensity stress factor is necessary to judge alumina tenacity. Final results in the two cases reveal the possibility of using alumina as a material of the humeral insert.
\end{abstract}

Keywords: Bioceramic, Prosthesis, Meshing, Tenacity, Limb.

DOI: 10.21272/jnep.12(6).06031

PACS number: 60.62

\section{INTRODUCTION}

The total shoulder prosthesis consists of a head and a cup. Usually the humeral component is made of metal. Various metals include stainless steel, tantalum, titanium, vanadium, cobalt, chromium, tungsten, nickel, and molybdenum and the cup is made of polymer (UHMWPE) [1]. For a cup made of polymer, debris providing from wear is considered to be the main reason causing the osteolysis as a result of biological reaction between tissues and polymer wear debris [2].

Stainless steel and metallic alloys have some disadvantages leading to post-operative pain (high weight compared to the human biological environment, significant thermal conductivity, possibility of oxidation by other agents which may exist in the human body). Metalose is an example of post-operative pain [4]. On the other hand, alumina, which is proposed to replace stainless steel, has the following advantages: biological inertness, high hardness $(\mathrm{HV}=2017 \mathrm{MPa})$, a low annual wear rate $(0.06 \mathrm{~mm} /$ year for a couple alumina/ UHMWPE), volume density $\left(3.9 \mathrm{~g} / \mathrm{cm}^{3}\right)$, high fineness (grain size $\leq 1.5 \mu \mathrm{m})$, high quality finish $(\leq 1.5 \mu \mathrm{m})$. The significant property making alumina a promoter material to replace metallic ones is wear resistance [9].

In addition to previous cited advantages, the main drawback of alumina is fragility (weak tenacity $\left.\leq 3.5 \mathrm{MPa}^{1 / 2}\right)[3,9]$.

It should be noted that the shoulder joint (glenohumeral joint) is subjected to heavy stresses due to the high mobility compared to other organs of the human body [5].

In this study, we seek to investigate the behavior of alumina as a proposed material of the head, basically its strength to crack propagation. First, we considered the total shoulder prosthesis and created a prior crack in two different locations of the head, the subject held his upper limb in abduction. We used Abaqus, known as finite elements code, to simulate the mechanical behavior of alumina in the presence of the prior crack, so two cases to be considered. Needed data were implemented in the software and we obtained results.

\section{MATERIAL AND METHODS}

\subsection{Loading and Boundary Conditions}

The subject undergoing total arthroplasty has a weight which is assumed to be $100 \mathrm{~kg}$.

The applied load is calculated according to Fig. 1, where the upper limb was in abduction in this position, the applied load is maximum. The weight of the upper limb was determined according to the subject's weight [6].

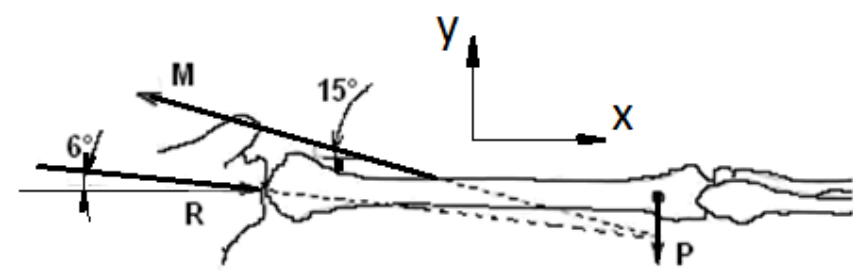

Fig. 1 - Loading in the abduction position [8]

$$
\left\{\begin{array}{l}
R \cos 6^{\circ}-M \cos 15^{\circ}=0 \\
M \sin 15^{\circ}-R \sin 6^{\circ}-P=0
\end{array}\right.
$$

where $P$ is the weight of the upper limb, $R$ is the contact force between the head and the cup.

After calculations, the obtained values of components of the contact force are illustrated in Table 1. 
Table 1 - Components of the contact force

\begin{tabular}{|l|l|l|l|}
\hline Forces & $R x(\mathrm{~N})$ & $R y(\mathrm{~N})$ & $R z(\mathrm{~N})$ \\
\hline Magnitude & 318.24 & 33.4 & 0 \\
\hline
\end{tabular}

To perform the simulation, taking into account loading conditions shown in Fig. 1, and to have contact between the head and the cup, an intermediate part was created which transmits the forces from the forearm to the contact point (Fig. 2).

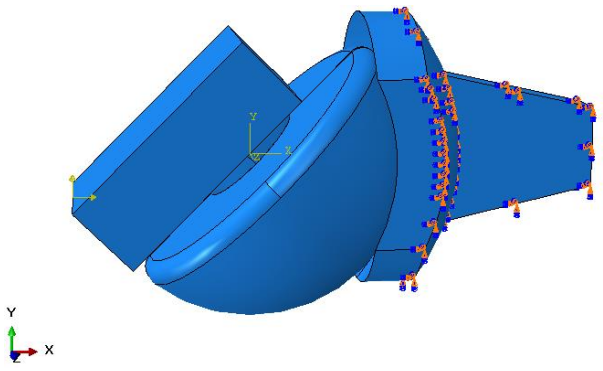

Fig. 2 - Loading and boundary conditions

The load providing from the forearm weight in abduction is applied on the intermediate part, and the cup is blocked.

\subsection{Mesh}

The two prior cracks were created on the outer edge $\left(\right.$ depth $=6 \mathrm{~mm}$, angle $\left.=45^{\circ}\right)$ and on the inner edge $\left(\right.$ depth $=4 \mathrm{~mm}$, angle $\left.=45^{\circ}\right)$. These values were overly adopted to investigate the tenacity of the head made from alumina. The used finite element is a four-node tetrahedron C3D4.

Table 2 - Data of the mesh

\begin{tabular}{|c|c|c|c|c|}
\hline \multirow{2}{*}{$\begin{array}{c}\text { Compo- } \\
\text { nents }\end{array}$} & \multicolumn{2}{|c|}{ Fist case } & \multicolumn{2}{c|}{ Second case } \\
\cline { 2 - 5 } & $\begin{array}{l}\text { Number of } \\
\text { elements }\end{array}$ & $\begin{array}{l}\text { Number of } \\
\text { nodes }\end{array}$ & $\begin{array}{l}\text { Number of } \\
\text { elements }\end{array}$ & $\begin{array}{l}\text { Number of } \\
\text { nodes }\end{array}$ \\
\hline Cup & 26226 & 5477 & 47332 & 9606 \\
\hline Head & 56089 & 11068 & 96092 & 18568 \\
\hline
\end{tabular}

\subsection{Materials of Implants}

The components of the shoulder total prosthesis, the head and the cup made, respectively, of alumina and UHMWPE, and their mechanical characteristics are illustrated in Table 3.

Table 3 - Characteristics of the materials

\begin{tabular}{|c|c|c|c|c|}
\hline $\begin{array}{c}\text { Compo- } \\
\text { nents }\end{array}$ & Material & $\begin{array}{c}\text { Young modu- } \\
\text { lus (MPa) }\end{array}$ & $\begin{array}{c}\text { Poisson } \\
\text { coefficient }\end{array}$ & $\begin{array}{c}\text { Tenacity } \\
\text { threshold } \\
\left({\left.\mathrm{MPa} . \mathrm{m}^{1 / 2}\right)}^{1 / 2}\right.\end{array}$ \\
\hline Head & alumina & 400000 & 0.28 & 3.5 \\
\hline Cup & UHMWPE & 1000 & 0.39 & - \\
\hline
\end{tabular}

All previous data were implemented in Abaqus which is the calculation tool using finite elements method.

\section{RESULTS AND DISCUSSION}

The results of simulation are limited to normal stresses $\sigma_{z z}$ which cause the crack lips to open (first mode of failure).
The distribution of $\sigma_{z z}$ on the head is shown by the following figure:

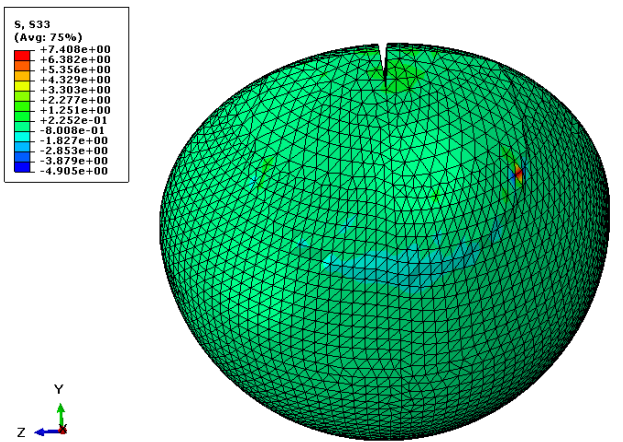

Fig. 3 - Distribution of stresses $\sigma_{z z}$ on the head

To determine the stress intensity factor $K_{I}$, the evolution of the normal stress $\sigma_{z z}$ in a given direction should be known. The investigation was performed on lines of crack propagation $\mathrm{AB}$ and $\mathrm{CD}$ in addition to the crack line EF.

The results are illustrated in Fig. 4.

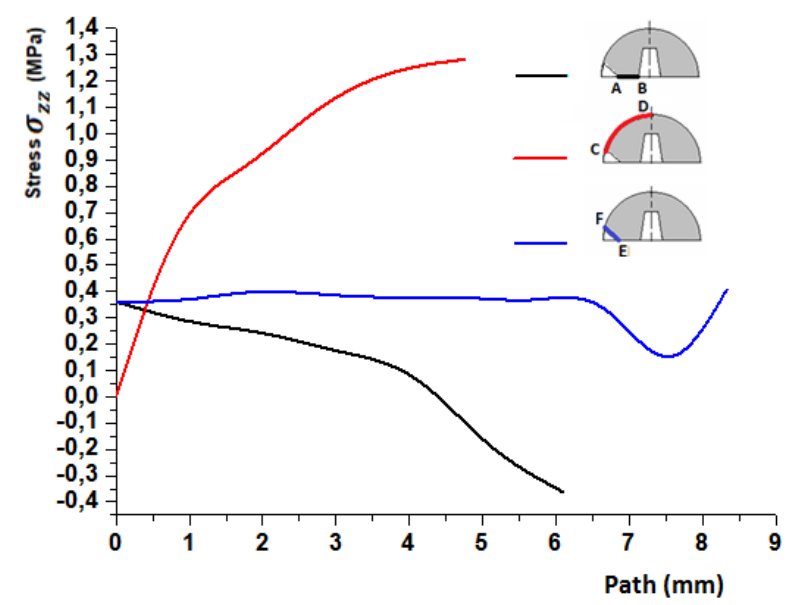

Fig. 4 - Evolution of stresses $\sigma_{z z}$ on investigation lines AB, CD and $\mathrm{EF}$ in the first case

The distribution of $\sigma_{z z}$ in the second case is shown by the following Fig. 5 .
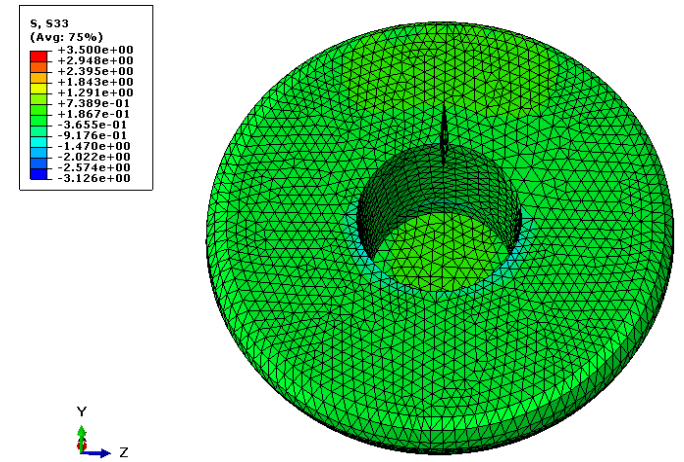

Fig. 5 - Distribution of stresses $\sigma_{z z}$ on the head

In the same way as the previous case, the investigation was performed on lines of crack propagation $A B$ and $\mathrm{CD}$ in addition to the crack line $\mathrm{EF}$ and the results are presented in Fig. 6 . 


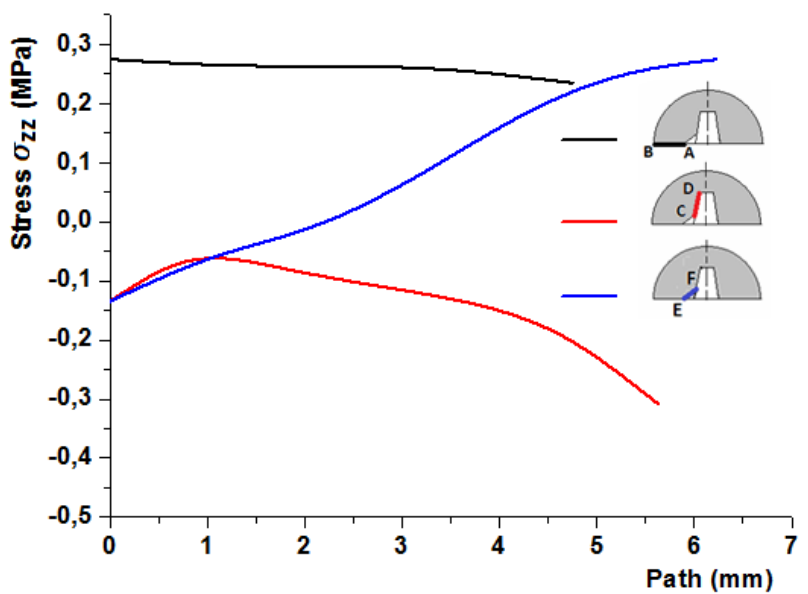

Fig. 6 - Evolution of stresses $\sigma_{z z}$ on investigation lines $\mathrm{AB}, \mathrm{CD}$ and $\mathrm{EF}$ in the second case

The failure can be in one of the following 3 modes.
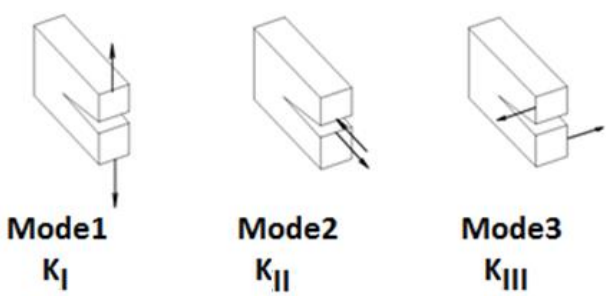

Fig. 7 - The three modes of failure

Mode 1 is considered the most dangerous; therefore, to check the strength of the crack propagation, we calculate the stress intensity factor $K_{I}$.

The relationships between stresses and the stress intensity factor are given by the following expression [7]:

$$
\lim _{r \rightarrow 0} \sigma_{i j}^{(I)}=\frac{K_{I}}{\sqrt{2 \pi r}} f_{i j}^{(I)}(\theta)
$$

The extrapolation method was used to determine $K_{I}$ considering the following relations:

$$
\begin{gathered}
K_{I}=\sigma_{z z} \sqrt{2 \pi r} \\
K_{I}(r)=K_{I}\left(r_{0}\right)+\frac{\Delta K_{0}}{h}\left(r-r_{0}\right)+\frac{\Delta^{2} K_{0}}{2 ! h^{2}}\left(r-r_{0}\right)\left(r-r_{1}\right)+ \\
\cdots+\frac{\Delta^{2} K_{0}}{2 ! h^{2}}\left(r-r_{0}\right)\left(r-r_{1}\right) \cdots\left(r-r_{n-1}\right)
\end{gathered}
$$

where $r_{i}(i=0, n-1)$ are the interpolating data points; $\Delta^{j} K_{0}(j=1, n)$ are the progressive finite differences; $h=r_{i+1}-r_{j}$ is the distance between two consecutive data points. The results of the calculation were put in Table 4.

Considering the first case. Fig. 3 shows that the values of normal stresses $\sigma_{z z}$ do not exceed 7.4 MPa. The evolution of the stress $\sigma_{z z}$ on the lines $\mathrm{AB}, \mathrm{CD}$ and $\mathrm{EF}$ is shown in Fig. 4. On the $\mathrm{AB}$ line, the evolution of $\sigma_{z z}$ looks as a relaxation and at the tip (point $\mathrm{A}$ ) of the crack $\sigma_{z z}=0.4 \mathrm{MPa}$, and in the vicinity of the conical hole (point B) $\sigma_{z z}=-0.4 \mathrm{MPa}$ which is due to compressive loading. On the CD line, the stress $\sigma_{z z}$ decreases from $0.4 \mathrm{MPa}$ at the circumferential tip of the crack until - $1 \mathrm{MPa}$ at the contact area between the head and the cup and it is zero at the top of the head. Evolution on the line EF reveals that $\sigma_{z z}$ is almost constant and positive on the $3 / 4$ of the line of the crack and does not exceed $0.4 \mathrm{MPa}$.

Table 4 - Values of the stress intensity factor $K_{I}$ for the two cases

\begin{tabular}{|c|c|c|c|}
\hline & $\begin{array}{c}\text { Line of } \\
\text { extrapolation }\end{array}$ & $\begin{array}{c}\text { Number } \\
\text { of data points }\end{array}$ & $\begin{array}{c}\text { Stress inten- } \\
\text { sity factor } K_{I}\end{array}$ \\
\hline First case & AB & 6 & 0.384 \\
\hline Second case & AB & 5 & 0.089 \\
\hline
\end{tabular}

Considering the second case. The Fig. $5 \sigma_{z z}$ values are limited to $3.5 \mathrm{MPa}$. In Fig. 6, it is observed a little relaxation of the stress $\sigma_{z z}$ along the line $\mathrm{AB}$ from 0.275 to $0.030 \mathrm{MPa}$. The same figure shows a decrease in the compressive stress $\sigma_{z z}$ along the line CD that is due to the applied load of the head. Finally, on the line of the crack EF the considered figure shows that the stress $\sigma_{z z}$ is almost positive along it and increases from -0.13 to $0.3 \mathrm{MPa}$. By using extrapolation, the stress intensity factor $K_{I}$ is determined by the expression (4). In both cases, the obtained values of the stress intensity factor $K_{I}$ seem to be much lower than the tenacity threshold of alumina (3.5 MPa.m ${ }^{1 / 2}$ ) (Table 4).

\section{CONCLUSIONS}

As indicated earlier, the aim of this work is to study the possibility of crack propagation of alumina selected as a material to replace stainless steel; the component of the total shoulder prosthesis intended to be studied is the head.

To judge if alumina can be used as a head material, we investigated its tenacity by finite elements method using the Abaqus software.

To carry out the study in this paper, we first considered the position of the load, i.e. the upper limb is in abduction, and the applied forces were determined. We then considered the geometry of different components and their material properties.

We created a prior crack in two different positions, and different lines of investigation were selected to expand the study. For each case, we considered the appropriate geometry and implemented all necessary data. The numerical simulation allowed to obtain the results of distribution of normal stresses $\sigma_{z z}$ which appear lower than expected, and the calculated values of the stress intensity factor $K_{I}$ are much lower than alumina tenacity one. To conclude, this study confirms the strength of alumina to cracking under the applied loading, therefore it can be used as the material of the head of the shoulder prosthesis. 


\section{REFERENCES}

1. https://www.orthonorcal.com/blog/shoulder-replacement surgery-21400.html.

2. P. Zeng, Journal Tribology - Materials, Surfaces \& Interfaces, 2 No 2, 109 (2008)

3. Samir Hamza, Étude du comportement en fatigue en compression des biocéramiques $\left(\mathrm{Al}_{2} \mathrm{O}_{3}, \mathrm{ZrO}_{2}\right)$ utilisées pour la conception des prothèses ostéo-articulaires. Thèse doctorat Université de Metz (2002).

4. E. Carré, D. Hartmann, Prothèses de genou Matériaux, fabrication et Classification, ACOPHRA (2007).
5. C. Klemt, J.A. Prinold, S. Morgans, S.H.L. Smith, D. Nolte, P. Reilly, A.M.J. Bull, Clinical Biomech. 54, 34 (2018).

6. Aydın Tözeren, Human Body Dynamics Classical Mechanics and Human Movement (Springer-Verlag: New York Inc.: 2000).

7. A.T. Zehnder, M.J. Viz, Appl. Mech. Rev. 58, 37 (2005).

8. Drouin et al., Biomécanique du mouvement humain (Décarie: Québec: 1986).

9. J.R. Jeffers, W.L. Walter, J. Bone Joint Surg. Br. 94 No 6 , 735 (2012).

\title{
Моделювання поведінки тріснутої головки плечового протеза
}

\author{
Belkacem Meddour \\ Laboratoire d'Ingénierie et Sciences des Matériaux Avancés ISMA, \\ Department of Mechanical Engineering, Abbas Laghrour University, Khenchela, Algeria
}

Безпека здоров'я людей є однією з найважливіших цілей урядів країн всього світу. Припинення функціонування будь-якого органу людського тіла може призвести до негативного психологічного та фізичного стану пацієнта. Заміна пошкодженого органу штучним у роботі розглянута на прикладі плечового суглобу, повний протез якого може бути імплантований для відновлення фрункціонування верхньої кінцівки. Правильний вибір матеріалів для такого протезування є одним із сучасних напрямів досліджень. Метою даної роботи є прогнозування поширення тріщини, штучно створеної в головці плечового протеза. Плечовий протез складається з двох компонентів: головки, виготовленої, як правило, із нержавіючої сталі або металевих сплавів, та чашки, яка може бути виготовлена 3 поліетилену з надвисокою молекулярною масою (UHMWPE). Запропонованим матеріалом головки є біокерамічний глинозем, властивості якого роблять його перспективним матеріалом для заміни нержавіючої сталі або металевих сплавів. Але найбільш небажаною властивістю глинозему є крихкість. Тому для дослідження міцності глинозему були попередньо штучно створені дефекти, а для розширення експерименту були розглянуті два випадки розташування попередньо створеної тріщини. Дослідження проводились методом моделювання з використанням коду обчислення кінцевих елементів Abaqus. Bихідні дані: реалізовано геометрію двох складів плечового протеза при навантаженні та вивчено механічні властивості розглянутого матеріалу. Отримані результати стосувались нормальних напружень на верхівці та лінії поширення попередньо створених трішин. Для оцінки міцності глинозему проведено розрахунок коефіціента інтенсивності напруженості. Остаточні результати у двох випадках виявляють можливість використання глинозему як матеріалу плечової вставки.

Ключові слова: Біокераміка, Протез, З'єднання, Міцність, Кінцівка. 